\title{
Cardiac Dysfunction Occurs in the HIV-1 Transgenic Mouse Treated with Zidovudine
}

\author{
William Lewis, Ingrid L. Grupp, Günter Grupp, Brian Hoit, Randal Morris, \\ Allen M. Samarel, Leslie Bruggeman, and Paul Klotman \\ Departments of Pathology (WL), Pharmacology (ILG), Physiology (GG), Medicine (BH), and Cell Biology (RM), \\ University of Cincinnati College of Medicine, Cincinnati Ohio; Cardiovascular Institute (AMS), Stritch School of \\ Medicine, Loyola University Chicago, Maywood, Illinois; and Department of Medicine (LB, PK), Mount Sinai School \\ of Medicine, New York, New York
}

SUMMARY: Cardiomyopathy in AIDS is an increasingly important clinical problem. Mechanisms of AIDS cardiomyopathy were explored using AIDS transgenic mice that express replication-incompetent HIV-1 (NL4-3 $\Delta$ gag/pol). Transgenic and FVB/n mice ( $n=3$ to 6 per cohort) received water ad libitum with and without zidovudine ( $3^{\prime}$-azido-2', $3^{\prime}$-deoxythymidine; AZT; $\left.0.7 \mathrm{mg} / \mathrm{ml}\right)$ for 21 or 35 days. After 21 days, echocardiographic studies were performed and abundance of mRNA for cardiac sarcoplasmic reticulum calcium ATPase (SERCA2), sodium calcium exchanger (NCX1), and atrial natriuretic factor were determined individually using Northern analysis of extracts of left ventricles. After 35 days, contractile function and relaxation were analyzed in isolated work-performing hearts. Histopathological and ultrastructural (transmission electron microscopy) changes were identified. After 21 days, molecular indicators of cardiac dysfunction were found. Depressed SERCA2 and increased atrial natriuretic factor mRNA abundance occurred in left ventricles from AZT-treated transgenic mice. NCX1 abundance was unchanged. Eccentric left ventricle hypertrophy was determined echocardiographically. After 35 days, cardiac dysfunction was worst in AZT-treated and AZT-untreated transgenic mice. Decreases in the first derivative of the maximal change in left ventricle systolic pressure with respect to time $(+\mathrm{d} P / \mathrm{d} t)$ occurred in transgenic mice with and without $A Z T$. Increased half-time of relaxation and ventricular relaxation $(-\mathrm{d} P / \mathrm{d} t)$ occurred in AZT-treated and -untreated transgenic mice. Increased time to peak pressure was found only in AZT-treated transgenic mice. In AZT-treated FVB/n mice, $-\mathrm{d} P / \mathrm{d} t$ was decreased. Ultrastructurally, mitochondrial destruction was most pronounced in AZT-treated transgenic mice, but also was found in AZT-treated FVB/n mice. Transgenic mice that express HIV-1 demonstrate cardiac dysfunction. AZT treatment of FVB/n mice causes mitochondrial ultrastructural alterations that are similar to those in other species. In transgenic mice, AZT treatment worsens molecular and ultrastructural features of cardiomyopathy. HIV-1 constructs and AZT each contribute to cardiac dysfunction in this murine model of AIDS cardiomyopathy. (Lab Invest 2000, 80:187-197).

$A$ IDS cardiomyopathy (CM) was described more than a decade ago (Cohen et al, 1986), and is gaining clinical importance (Barbaro et al, 1998). In patients with advanced AIDS, $8 \%$ had CM (De Palo et al, 1995). A similar proportion was found in hemophiliacs with AIDS (Jacob et al, 1993). With the advent of effective treatment of AIDS complications and increasing survival with AIDS, it seems logical that $\mathrm{CM}$ will become a prevalent clinical problem (Currie and Boon, 1983; Hsia et al, 1993).

To date, clinical studies fail to elucidate the etiology or pathogenesis of AIDS CM and thus mechanisms of AIDS CM remain a mystery. Myocardial filling and relaxation abnormalities were found in AIDS patients' echocardiographs (Barbaro et al, 1996; Cardoso et al, 1998; Coudray et al, 1995) and became early indicators of CM.

Received June 28, 1999.

Supported by 5 R01 HL59798 to WL.

Address reprint requests to: $D r$. W. Lewis, Department of Pathology, Emory University School of Medicine ML 529, 7117 Woodruff Memorial Building, 1639 Pierce Drive, Atlanta, Georgia 30322. Fax: (404) 727-8540; E-mail:wlewis@emory.edu
Many etiologies and pathogeneses are postulated for AIDS CM (Lewis, 1998; Michael et al, 1997) and it is possible that more than one etiology may contribute to $\mathrm{CM}$ development in the same AIDS patient. Potential etiologies include direct HIV-1 infection of the heart (Barbaro et al, 1998; Calabrese et al, 1987; Grody et al, 1990; Lipshultz et al, 1990; Wu et al, 1990), myocarditis caused by HIV-1 or by concomitant (or opportunistic) myocardial infection (Anderson et al, 1988; Barbaro et al, 1998; Reilly et al, 1988), cardiotoxicity of prolonged administration of antiviral therapeutics including zidovudine (AZT; 3'-azido-2', 3'-deoxythymidine; Dalakas et al, 1991; Herskowitz et al, 1992; Lewis et al, 1991) or other agents, cardiodepressant effects from localized or systemic cytokine expression, cardiotoxicity of illicit or selfprescribed drugs (particularly alcohol, cocaine, or heroin) or pharmaceuticals, and toxicity of home remedies (reviewed in Lewis, 1998; Lewis and Dalakas, 1995).

The hemizygous NL4-3 $\mathrm{gag} / \mathrm{pol}$ transgenic mouse (TG) contains an internal deletion of the gag/pol coding sequence that renders the viral construct replicationincompetent, non-infectious, relatively easy to handle, and useful to study AIDS CM (Bruggeman et al, 1997; Klotman and Notkins, 1996; Kopp et al, 1992). 
Phenotypic changes of AIDS in the TG attest to the authenticity of the model and include AIDS nephropathy (Bruggeman et al, 1997), failure to thrive and wasting (of pups; Kopp et al, 1992), and dermatological lesions (Kopp et al, 1993). Because the TG genetic background is $\mathrm{FVB} / \mathrm{n}, \mathrm{FVB} / \mathrm{n}$ wild type mice served as controls (WT).

Using a mouse model system, experiments here dissect the role of a transgenically inserted, replication incompetent HIV-1 cDNA construct on the development of CM in AIDS. Treatment of these mice with $A Z T$, the principal antiretroviral agent used in AIDS, was initiated to mimic therapeutic intervention and to define cardiotoxicity.

\section{Results}

General. All groups of mice survived for the duration of the 21-day and 35-day experiments. Heart weights (mg; mean \pm standard deviation SD) were determined after 35 days. The heart rates ranged from $161 \pm 30$ for untreated WT to $221 \pm 36$ in AZT-treated TG (37\% increase above WT; $p<0.01$; Table 1).

AZT Consumption Data. TG and WT each consumed $A Z T$ in drinking water. Consumption of $A Z T$ was 182 to $215 \mathrm{mg} / \mathrm{kg} /$ day.

Physiological Changes in the Isolated WorkPerforming Hearts of AIDS Transgenic Mice at 35 Days. Contractile dysfunction was observed in the TG. Figure 1 is a composite of histograms depicting cardiac performance in all of the groups used in these experiments. Parameters evaluated included the first derivatives of maximal changes, with respect to time, in LV systolic pressure $(+\mathrm{d} P / \mathrm{d} t)$ and $\mathrm{LV}$ relaxation $(-\mathrm{d} P / \mathrm{d} t)$, time to peak pressure $(\mathrm{TPP} / \mathrm{mmHg})$, and half time of relaxation $\left(\mathrm{RT}_{1 / 2} / \mathrm{mmHg}\right)$. All groups were initially compared at identical preloads and afterloads and similar heart rates (approximately 320 beats/ minute).

$+\mathrm{d} P / \mathrm{d} t$ showed a small but significant decrease $(p<0.01)$ in untreated TG, compared with the untreated WT. Ventricular relaxation $(-\mathrm{d} P / \mathrm{d} t)$ revealed a significant decrease in rate in AZT-treated WT $(p<$ 0.01 ) and $A Z T$-treated TG, but untreated TG also demonstrated defective relaxation $(p<0.001$ respectively). $R T_{1 / 2} / \mathrm{mmHg}$ increased significantly in AZTtreated and -untreated TG $(p<0.05)$ and a small increase in TPP/mmHg was found in AZT-treated TG. Tables 2 through 5 present the numerical summaries of all measured and derived physiological measure-

Table 1. Heart Weight and Body Weight of TG and WT

\begin{tabular}{lccc}
\hline \multicolumn{1}{c}{ Group } & $\begin{array}{c}\text { Heart } \\
\text { weight } \\
(\mathrm{mg})\end{array}$ & $\begin{array}{c}\text { Body } \\
\text { weight } \\
(\mathrm{g})\end{array}$ & $\begin{array}{c}\text { Heart/Body } \\
\text { weight } \\
(\mathrm{mg} / \mathrm{g})\end{array}$ \\
\hline $\mathrm{WT}(\mathrm{n}=7)$ & $161 \pm 30$ & 24.7 & 6.5 \\
WT + AZT $(\mathrm{n}=4)$ & $201 \pm 46$ & 26.6 & 7.6 \\
TG $(\mathrm{n}=5)$ & $198 \pm 31$ & 23.2 & 8.5 \\
TG + AZT $(\mathrm{n}=5)$ & $221 \pm 36^{*}$ & 24.3 & $9.1^{*}$ \\
\hline
\end{tabular}

${ }^{*} p<0.01$ compared with WT.

$\mathrm{TG}$, transgenic mouse; WT, wild type mouse.

\section{Baseline}
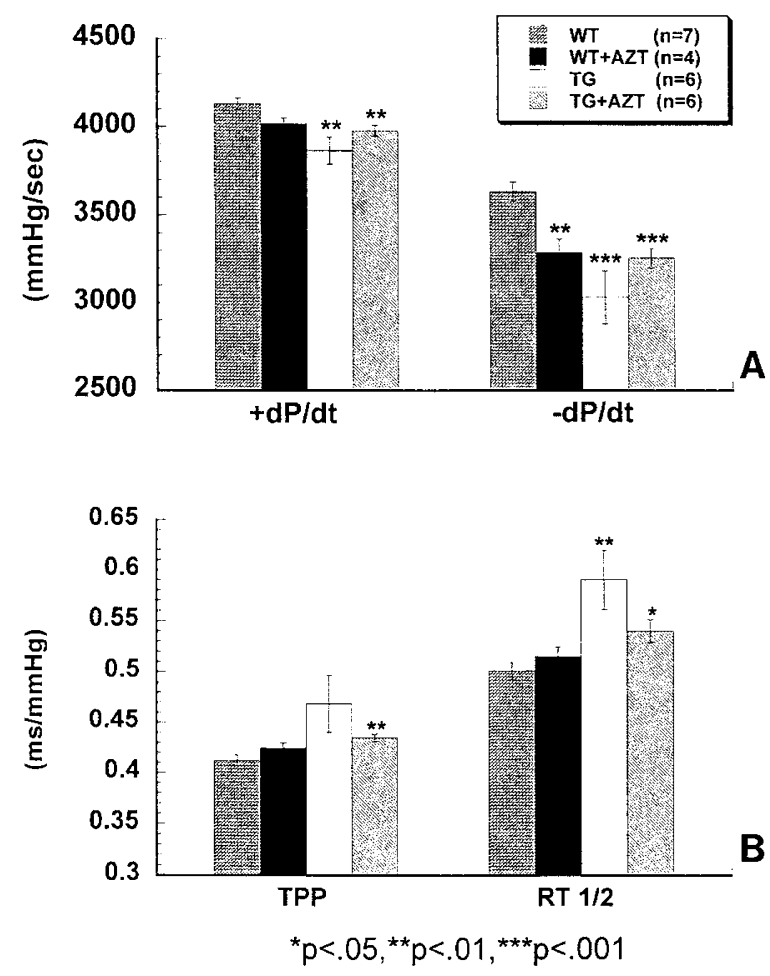

Figure 1.

Myocardial contractile parameters $(+\mathrm{dP} / \mathrm{dt}$ in $\mathrm{mmHg} / \mathrm{seconds}$ and $\mathrm{TPP} / \mathrm{mmHg}$ in $\mathrm{ms} / \mathrm{mmHg}$ of intraventricular pressure) and relaxation parameters $(-\mathrm{dP} / \mathrm{d} t$ in $\mathrm{mmHg} / \mathrm{second}$ and $\mathrm{RT}_{1 / 2} / \mathrm{mmHg}$ in $\mathrm{ms} / \mathrm{mmHg}$ of intraventricular pressure) of NL4-3 gag/po/ wildtype mice (WT), WT treated with zidovudine (3'-azido$2^{\prime}, 3^{\prime}$-deoxythymidine; AZT), transgenic mice (TG), and TG treated with AZT, tested in work-performing heart preparations under identical loading conditions. Basal loading was $5 \mathrm{ml} /$ minute cardiac output and $50 \mathrm{mmHg}$ mean aortic pressure. Heart rates were approximately 315 beats/minute and work load was $250(\mathrm{mmHg} \times \mathrm{ml} / \mathrm{minute})$. A, A decrease in the rate of pressure development $(+\mathrm{d} P / \mathrm{d} t)$ is present in both AZT-treated and untreated TG. Changes in the rate of relaxation $(-\mathrm{d} P / \mathrm{d} t)$ are decreased in AZT-treated TG and WT and in untreated TG. B, TPP/mmHg is increased in AZT-treated TG. $R T_{1 / 2} / \mathrm{mmHg}^{2}$ increased dramatically in $\mathrm{TG}$ with and without AZT treatment.

ments in the histograms. Physiological data above and pathological data below indicate that both AZT and HIV-1 each play a role in the development of CM, although possibly through different pathophysiologic mechanisms.

It was of great importance to evaluate the performance of all hearts in all groups during decreases and increases of afterload and preload. Changes in afterload were achieved by decreasing and increasing aortic pressure. Changes in preload were accomplished by decreasing and increasing venous return. Stepwise decreases of pressure load were tolerated in all groups with respect to contraction $(+\mathrm{d} P / \mathrm{d} t$ and $\mathrm{TPP} / \mathrm{mmHg}$ of intraventricular pressure [IVP]). However, the relaxation parameters $\left(-\mathrm{d} P / \mathrm{d} t\right.$ and $\mathrm{RT}_{1 / 2} /$ $\mathrm{mmHg}$ of IVP) showed significant impairment in both 
Table 2. Minimum Pressure Loading

\begin{tabular}{lcccc}
\hline \multicolumn{1}{c}{ Parameter } & $\begin{array}{c}\text { WT } \\
(\mathrm{n}=7)\end{array}$ & $\begin{array}{c}\text { WT }+ \text { AZT } \\
(\mathrm{n}=4)\end{array}$ & $\begin{array}{c}\text { TG } \\
(\mathrm{n}=5)\end{array}$ & $\begin{array}{c}\text { TG }+ \text { AZT } \\
(\mathrm{n}=5)\end{array}$ \\
\hline Heart rate $(\mathrm{Bpm})$ & $307.7 \pm 19.1$ & $328.0 \pm 20.7$ & $311.0 \pm 20.3$ & $300.0 \pm 23.5$ \\
$\mathrm{MAP}(\mathrm{mmHg})$ & $30.4 \pm 0.3$ & $30.3 \pm 0.3$ & $32.3 \pm 1.7$ & $32.2 \pm 2.0$ \\
$\mathrm{EDP}(\mathrm{mmHg})$ & $4.86 \pm 0.8$ & $5.3 \pm 0.9$ & $10.5 \pm 4.2$ & $7.0 \pm 2.2$ \\
$+\mathrm{dP} / \mathrm{dt}(\mathrm{mmHg} / \mathrm{sec})$ & $3404.6 \pm 106.8$ & $3136.0 \pm 92.3$ & $3188.0 \pm 164.7$ & $3096.0 \pm 107.9$ \\
$-\mathrm{dP} / \mathrm{dt}(\mathrm{mmHg} / \mathrm{sec})$ & $-2965.7 \pm 115.1$ & $-2472.0 \pm 216.4$ & $-2380.0 \pm 178.0^{*}$ & $-2260.8 \pm 119.4^{* *}$ \\
$\mathrm{TPP} / \mathrm{mmHg}(\mathrm{msec} / \mathrm{mmHg})$ & $0.505 \pm 0.02$ & $0.533 \pm 0.02$ & $0.546 \pm 0.04$ & $0.542 \pm 0.02$ \\
$\mathrm{RT} T_{1 / 2}(\mathrm{msec} / \mathrm{mmHg})$ & $0.554 \pm 0.02$ & $0.617 \pm 0.04$ & $0.652 \pm 0.04^{*}$ & $0.702 \pm 0.06^{*}$ \\
$\mathrm{CO}(\mathrm{ml} / \mathrm{min})$ & $5.17 \pm 0.04$ & $5.2 \pm 0.06$ & $5.1 \pm 0.04$ & $5.12 \pm 0.04$ \\
Work & $156.3 \pm 1.3$ & $156.7 \pm 3.3$ & $163.8 \pm 9.1$ & $163.8 \pm 10.0$ \\
Coronary flow $(\mathrm{ml} / \mathrm{min})$ & $1.27 \pm 0.3$ & $1.2 \pm 0.2$ & $1.2 \pm 0.2$ & $1.93 \pm 0.5$ \\
Aortic flow $(\mathrm{ml} / \mathrm{min})$ & $3.89 \pm 0.3$ & $4.0 \pm 0.1$ & $3.88 \pm 0.2$ & $3.18 \pm 0.5$ \\
\hline
\end{tabular}

${ }^{\star} p<0.05,{ }^{* *} p<0.01,{ }^{* * *} p<0.001$

Table 3. Maximum Pressure Loading

\begin{tabular}{|c|c|c|c|c|}
\hline Parameter & $\begin{array}{c}\text { WT } \\
(n=7)\end{array}$ & $\begin{array}{c}W T+A Z T \\
(n=4)\end{array}$ & $\begin{array}{c}T G \\
(n=5)\end{array}$ & $\begin{array}{c}\mathrm{TG}+\mathrm{AZT} \\
(\mathrm{n}=5)\end{array}$ \\
\hline Heart rate $(\mathrm{Bpm})$ & $325.0 \pm 8.8$ & $356.8 \pm 14.9$ & $377.8 \pm 13.9$ & $346.3 \pm 15.7$ \\
\hline MAP $(\mathrm{mmHg})$ & $86.7 \pm 1.8$ & $85.3 \pm 3.0$ & $84.3 \pm 3.5$ & $81.17 \pm 4.5$ \\
\hline $\mathrm{EDP}(\mathrm{mmHg})$ & $8.9 \pm 1.6$ & $8.5 \pm 3.3$ & $13.3 \pm 3.1$ & $7.8 \pm 1.5$ \\
\hline$+\mathrm{dP} / \mathrm{dt}(\mathrm{mmHg} / \mathrm{sec})$ & $5640.0 \pm 141.6$ & $5520.0 \pm 319.8$ & $5632.0 \pm 222.0$ & $5556.0 \pm 312.1$ \\
\hline$-\mathrm{dP} / \mathrm{dt}(\mathrm{mmHg} / \mathrm{sec})$ & $-4738.3 \pm 214.0$ & $-4296.0 \pm 402.4$ & $-4576.0 \pm 284.8$ & $-4464.0 \pm 121.8$ \\
\hline $\mathrm{TPP} / \mathrm{mmHg}(\mathrm{msec} / \mathrm{mmHg})$ & $0.3064 \pm 0.01$ & $0.3185 \pm 0.02$ & $0.3141 \pm 0.01$ & $0.3158 \pm 0.02$ \\
\hline $\mathrm{RT}_{1 / 2}(\mathrm{msec} / \mathrm{mmHg})$ & $0.4513 \pm 0.02$ & $0.4495 \pm 0.01$ & $0.4376 \pm 0.02$ & $0.445 \pm 0.03$ \\
\hline $\mathrm{CO}(\mathrm{ml} / \mathrm{min})$ & $5.057 \pm 0.04$ & $5.2 \pm 0.00$ & $5.2 \pm 0.03$ & $5.13 \pm 0.05$ \\
\hline Work & $436.3 \pm 9.9$ & $438.8 \pm 14.5$ & $432.2 \pm 19.2$ & $414.7 \pm 25.0$ \\
\hline Coronary flow (ml/min) & $3.1 \pm 0.4$ & $3.9 \pm 0.5$ & $3.5 \pm 0.3$ & $3.8 \pm 0.4$ \\
\hline Aortic flow (ml/min) & $1.9 \pm 0.4$ & $1.3 \pm 0.5$ & $1.6 \pm 0.4$ & $1.38 \pm 0.4$ \\
\hline
\end{tabular}

${ }^{*} p<0.05,{ }^{* *} p<0.01,{ }^{* * *} p<0.001$

Table 4. Minimum Volume Loading

\begin{tabular}{lcccc}
\hline \multicolumn{1}{c}{ Parameter } & $\begin{array}{c}\text { WT } \\
(\mathrm{n}=7)\end{array}$ & $\begin{array}{c}\text { WT }+ \text { AZT } \\
(\mathrm{n}=4)\end{array}$ & $\begin{array}{c}\text { TG } \\
(\mathrm{n}=5)\end{array}$ & $\begin{array}{c}\text { TG }+ \text { AZT } \\
(\mathrm{n}=5)\end{array}$ \\
\hline Heart rate $(\mathrm{Bpm})$ & $299.1 \pm 20.2$ & $286.3 \pm 27.9$ & $293.0 \pm 15.6$ & $314.67 \pm 13.3$ \\
$\mathrm{MAP}(\mathrm{mmHg})$ & $34.57 \pm 3.3$ & $34.7 \pm 1.5$ & $31.3 \pm 2.0$ & $37.0 \pm 2.6$ \\
$\mathrm{EDP}(\mathrm{mmHg})$ & $4.14 \pm 0.4$ & $3.7 \pm 0.9$ & $6.8 \pm 2.3$ & $5.7 \pm 1.0$ \\
$+\mathrm{dP} / \mathrm{dt}(\mathrm{mmHg} / \mathrm{sec})$ & $2890.3 \pm 178.3$ & $2880 \pm 104.6$ & $2708.0 \pm 91.2$ & $2804.0 \pm 120.2$ \\
$-\mathrm{dP} / \mathrm{dt}(\mathrm{mmHg} / \mathrm{sec})$ & $-2149.7 \pm 120.0$ & $-1848.0 \pm 183.3$ & $-1780.0 \pm 76.3^{*}$ & $-1804.0 \pm 94.3^{*}$ \\
$\mathrm{TPP} / \mathrm{mmHg}(\mathrm{msec} / \mathrm{mmHg})$ & $0.5913 \pm 0.04$ & $0.589 \pm 0.03$ & $0.6376 \pm 0.02$ & $0.6133 \pm 0.03$ \\
$\mathrm{RT} \mathrm{T}_{1 / 2}(\mathrm{msec} / \mathrm{mmHg})$ & $0.7177 \pm 0.041$ & $0.759 \pm 0.071$ & $0.8215 \pm 0.037$ & $0.8588 \pm 0.087$ \\
$\mathrm{CO}(\mathrm{ml} / \mathrm{min})$ & $3.11 \pm 0.03$ & $3.1 \pm 0.06$ & $3.3 \pm 0.1$ & $3.233 \pm 0.16$ \\
Work & $108.0 \pm 10.1$ & $108.0 \pm 5.7$ & $103.8 \pm 12.2$ & $121.7 \pm 15.4$ \\
Coronary flow $(\mathrm{ml} / \mathrm{min})$ & $1.11 \pm 0.22$ & $1.10 \pm 0.06$ & $1.15 \pm 0.14$ & $1.88 \pm 0.36$ \\
Aortic flow $(\mathrm{ml} / \mathrm{min})$ & $2.06 \pm 0.20$ & $2.07 \pm 0.07$ & $2.15 \pm 0.07$ & $7.52 \pm 6.0$ \\
\hline
\end{tabular}

${ }^{*} p<0.05,{ }^{* *} p<0.01,{ }^{* * *} p<0.001$

groups of TG and with or without AZT. In contrast, increasing pressure loads resulted in good Starling responses in all parameters for all groups (Fig. 2).

The physiological effects on TG were further analyzed by decreasing preload. Stepwise decreases of preload (volume reduction) to minimum venous return $(3 \mathrm{ml} / \mathrm{min})$ resulted in reduced relaxation rates $(-\mathrm{d} P$ / $\mathrm{d} t)$ in AZT-treated and AZT-untreated TG $(p<0.05)$.
Other parameters were not significantly affected (Fig. 3). Increasing preload (increasing venous return) showed only prolongation of contraction time (TPP/ $\mathrm{mmHg}$ ). All other parameters showed no significant change compared with the WT (Fig. 3).

Pathological Changes in Control and Transgenic Mice at 35 Days. Necropsies were performed on mice. Hearts revealed globular configuration in AZT-treated 
Table 5. Maximum Volume Loading

\begin{tabular}{|c|c|c|c|c|}
\hline Parameters & $\begin{array}{c}\text { WT } \\
(n=7)\end{array}$ & $\begin{array}{c}W T+A Z T \\
(n=4)\end{array}$ & $\begin{array}{c}T G \\
(n=5)\end{array}$ & $\begin{array}{c}T G+A Z T \\
(n=5)\end{array}$ \\
\hline Heart rate (Bpm) & $342.0 \pm 14$ & $348.0 \pm 16$ & $360.0 \pm 6.43$ & $354.3 \pm 12.17$ \\
\hline MAP (mmHg) & $64.1 \pm 3.5$ & $61.8 \pm 2.3$ & $64.0 \pm 2.30$ & $64.2 \pm 2.47$ \\
\hline $\mathrm{EDP}(\mathrm{mmHg})$ & $9.71 \pm 1.6$ & $12.3 \pm 3.8$ & $16.8 \pm 4.43$ & $9.833 \pm 2.21$ \\
\hline$+\mathrm{dP} / \mathrm{dt}(\mathrm{mmHg} / \mathrm{sec})$ & $5218.3 \pm 204.4$ & $5250.0 \pm 641.3$ & $4627.2 \pm 359.79$ & $5108.0 \pm 243.76$ \\
\hline$-\mathrm{dP} / \mathrm{dt}(\mathrm{mmHg} / \mathrm{sec})$ & $-4433.1 \pm 281.2$ & $-4284.0 \pm 640.0$ & $-3907.2 \pm 399.83$ & $-4344.0 \pm 282.62$ \\
\hline $\mathrm{TPP} / \mathrm{mmHg}(\mathrm{msec} / \mathrm{mmHg})$ & $0.3351 \pm 0.009$ & $0.3475 \pm 0.045$ & $0.3744 \pm 0.0180^{*}$ & $0.3407 \pm 0.0189$ \\
\hline $\mathrm{RT}_{1 / 2}(\mathrm{msec} / \mathrm{mmHg})$ & $0.465 \pm 0.03$ & $0.4435 \pm 0.06$ & $0.5266 \pm 0.038$ & $0.4657 \pm 0.039$ \\
\hline $\mathrm{CO}(\mathrm{mL} / \mathrm{min})$ & $6.8 \pm 0.2$ & $7.4 \pm 0.2$ & $7.1 \pm 0.3$ & $7.067 \pm 0.056$ \\
\hline Work & $439.9 \pm 34.9$ & $458.3 \pm 26.3$ & $451.8 \pm 22.96$ & $455.33 \pm 19.548$ \\
\hline Coronary flow (mL/min) & $3.1 \pm 0.4$ & $3.9 \pm 0.4$ & $3.76 \pm 0.607$ & $4.06 \pm 0.361$ \\
\hline Aortic flow (mL/min) & $3.7 \pm 0.5$ & $3.5 \pm 0.5$ & $3.28 \pm 0.441$ & $3.04 \pm 0.376$ \\
\hline
\end{tabular}

${ }^{*} p<0.05,{ }^{* *} p<0.01,{ }^{* * *} p<0.001$

TG. Cross-sections of myocardium taken at the base of the left ventricle (LV) papillary muscles from perfusion-fixed samples permitted visual comparison of the LV cavities in similar planes. LV cavity configurations were unremarkable in untreated $W T$ and $T G$ (Fig. 4, A and B). Hearts from WT and TG treated with AZT revealed increased LV cavity size (Fig. 4, C and D). Neither interstitial inflammation nor repair fibrosis was found.

Ultrastructural changes in cardiac myocytes were examined quantitatively in samples from treatment groups and their respective controls (Fig. 5, A and B compared with 5, C and D). Transmission electron microscope (TEM) photomicrographs of hearts of mice treated with $A Z T$ revealed ultrastructural changes in cardiac myocyte mitochondria that resembled those observed previously by us and by others. The characteristic features of damage from AZT included fragmentation of mitochondrial cristae and swelling (Fig. 5, C and D).

Morphometric analysis revealed cardiac mitochondrial damage that was greater in the AZT-treated TG than in untreated TG or AZT-treated WT (Table 6). Comparing AZT-treated WT with untreated WT, structural damage to mitochondria increased 5-fold. AZTtreated TG demonstrated a 19-fold increase in the abundance of damaged mitochondria over untreated WT.

Echocardiographic Findings. In WT, after 3 weeks of AZT treatment, the AZT treatment tended to increase LV end-diastolic dimension (EDD) ( $p=0.058)$, but did not reach a level of significance. However, the effects of AZT on LV end-systolic dimension (ESD) did reveal a significant increase. As a result, there was a significant $(30 \%)$ reduction in LV fractional shortening (Table 7). Accordingly, LV mass increased significantly without a change in geometry (ie, the ratio of wall thickness to cavity radius), indicating eccentric LV hypertrophy and cardiac remodeling.

Steady-State Abundance of Cardiac mRNA in TG and WT Treated With and Without AZT, at 21 Days. Figure $6 \mathrm{~A}$ is a composite histogram indicating the relative signal of atrial natriuretic factor (ANF) normalized to glyceraldehyde-3-phosphate dehydrogenase
(GAPDH) and compared with the control. Untreated TG females demonstrated a 1.8-fold increase in steady-state abundance of ANF mRNA compared with WT, a $22 \%$ decrease in SeRCa ATPase (SERCA2) mRNA, and essentially no change in $\mathrm{Na} / \mathrm{Ca}$ Exchanger (NCX1) mRNA. In contrast, female $\mathrm{WT}+\mathrm{AZT}$ revealed no change in ANF, a 24\% decrease in SERCA2 mRNA, and no change in NCX1 (Fig. 6, A to C).

SERCA2 mRNA abundance decreased significantly in both female AZT-treated WT and female TG compared with untreated, gender-matched WT. Untreated female TG demonstrated a $20 \%$ decrease in myocardial SERCA2 mRNA. The most profound effect on SERCA2 was found in AZT-treated TG of both genders; the observed decrease in SERCA2 mRNA exceeded 35\% in each (Fig. 6B).

Overall, the TG+AZT cohort demonstrated molecular features of cardiac dysfunction based on altered expression of these mRNA. Changes included 2- to 4-fold increase in ANF expression (both genders), approximately $35 \%$ decrease in SERCA2 (both genders), and no changes in NCX1 compared with controls.

\section{Discussion}

Using a transgenic AIDS model, this study addresses the contribution of HIV-1 (as expressed in a transgenic HIV-1 construct) and of AZT treatment on CM in AIDS. With increased survival of AIDS patients, an increase in the prevalence of AIDS CM may occur. Accordingly, the clinical importance of AIDS CM may rise.

Our data demonstrate that cardiac dysfunction is present in an established murine transgenic AIDS line (containing an HIV-1 construct). Although the TG construct alone was associated with cardiac dysfunction, and $A Z T$ treatment caused structural and functional changes in WT, antiretroviral treatment with AZT amplified cardiac dysfunction and worsened ultrastructural features of AIDS CM in TG. Physiological changes in contraction ( $+\mathrm{d} p / \mathrm{d} t$ or $\mathrm{TPP} / \mathrm{mmHg}$ ) and relaxation $\left(-\mathrm{d} P / \mathrm{d} t\right.$ and $\left.\mathrm{RT}_{1 / 2} / \mathrm{mmHg}\right)$ were found in AZT-treated and untreated TG. Alterations in relax- 

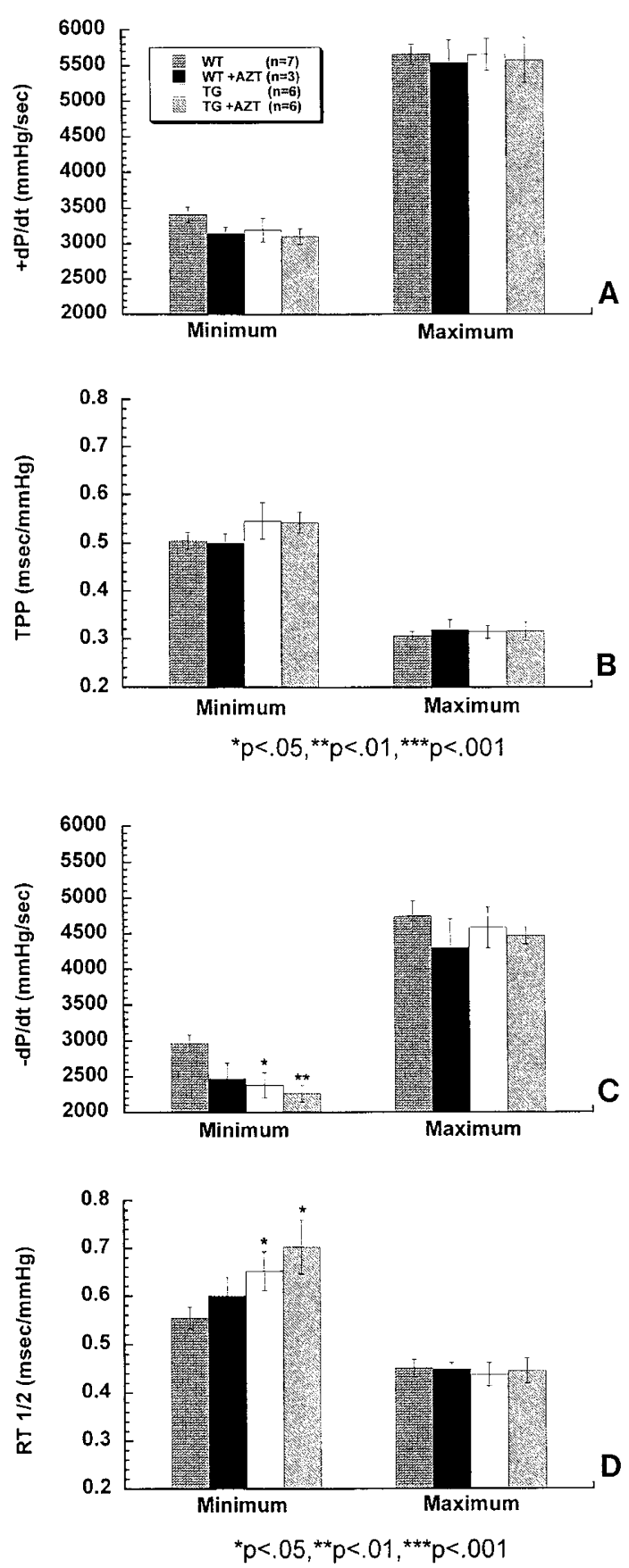

Figure 2.

A and B, Comparison of contractile parameters during pressure loading in TG and WT with and without AZT treatment. Venous return was kept constant at $5 \mathrm{ml} /$ minute. Minimum ranges of aortic pressure were approximately 30 $\mathrm{mmHg}$ and maximum ranges approximately $80 \mathrm{mmHg}$. The resulting work load was approximately $160 \mathrm{mmHg} \times \mathrm{ml} /$ minute during minimal loading, and 414 to $438 \mathrm{mmHg} \times \mathrm{ml} /$ minute during maximal loading. $\mathrm{C}$ and $\mathrm{D}$, Comparison of relaxation parameters during pressure loading.

ation $(-\mathrm{d} p / \mathrm{d} t)$ were found in AZT-treated WT. Molecular and echocardiographic changes early in treatment were consistent with a pathophysiologic picture of cardiac remodeling and dysfunction, which could lead to CM.

The overall response to loading of the hearts (pressure or volume, respectively) after 35 days AZT treat-
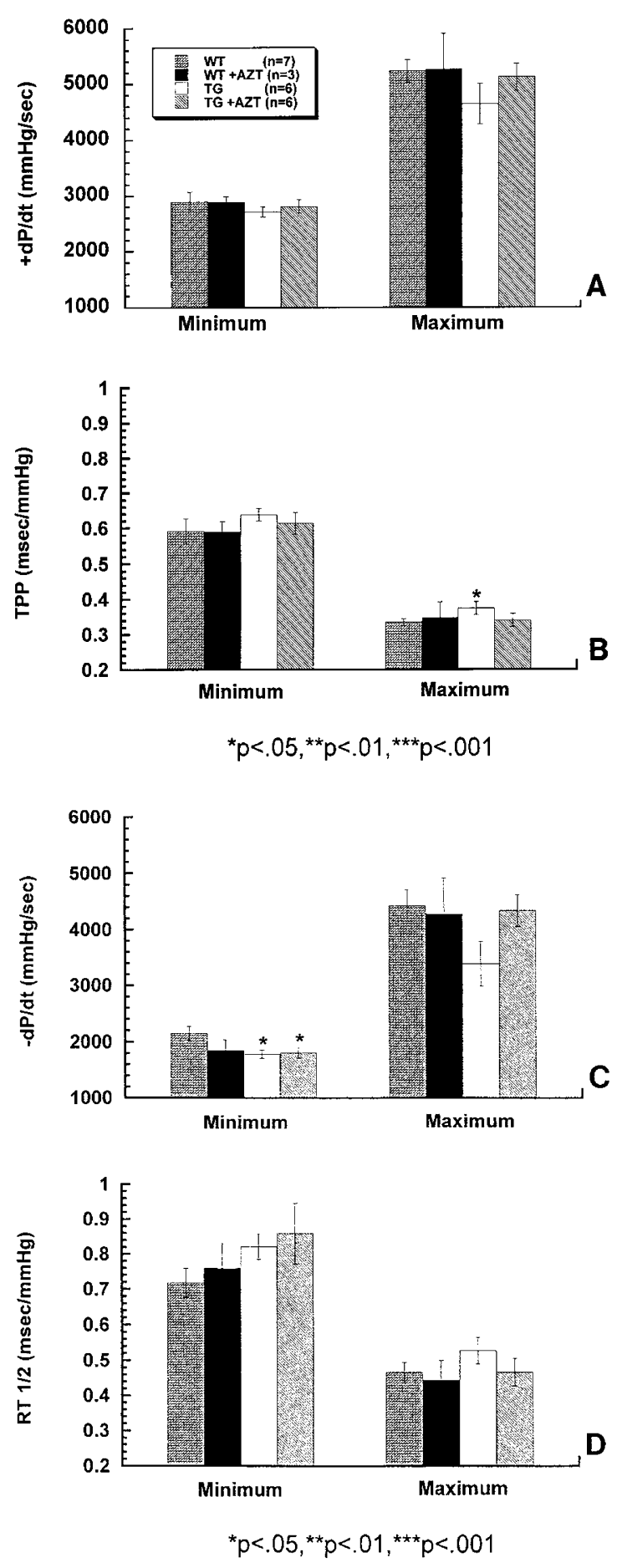

Figure 3.

A to D, Comparison of contractile and relaxation parameters of AZT-treated and untreated WT and TG during volume loading (minimum work load: 108 to 121 $\mathrm{mmHg} \times \mathrm{ml} /$ minute; maximum work load, 440 to $458 \mathrm{mmHg} \times \mathrm{ml} /$ minute).

ment indicated that both murine LV systolic and diastolic function was sensitive to the HIV-1 TG; this was particularly true with AZT treatment. Doseresponse curves indicated no change in response to isoproterenol amongst the groups (data not shown). This lack of response suggested that $\beta$-adrenergic receptor regulation may not be involved directly. 

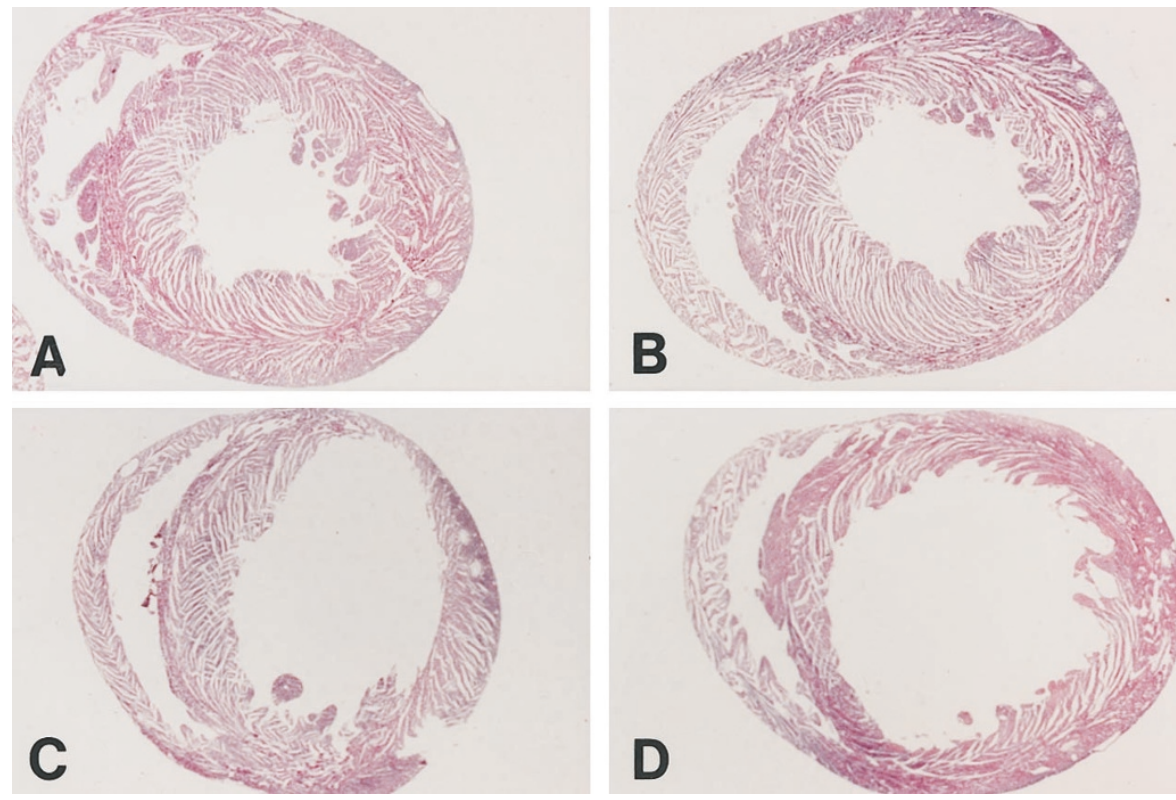

\section{Figure 4.}

Representative light photomicrographs from AZT-treated and untreated WT and TG. Upon completion of cardiac performance measurements, hearts were perfusion fixed in $10 \%$ neutral buffered formalin, serially sectioned from apex to base, and processed for routine histopathology. For ventricular chamber dimensions, sections were uniformly taken $3 \mathrm{~mm}$ from the cardiac apex. Both untreated WT (A) and untreated TG (B) mouse hearts reveal preservation of native left ventricular (LV) and right ventricular (RV) configuration. With AZT treatment (lower two panels), hearts from both WT (C) and TG (D) mice reveal dilation of the LV chamber. More dilation seems to be present in the AZT-treated TG than in the AZT-treated WT. (Original magnification, $\times 7$.)

Pathological changes were found in the hearts of TG and WT treated with AZT for 35 days. Cardiomegaly in AZT-treated TG correlated with increased LV cavity size. Characteristic mitochondrial ultrastructural changes of AZT CM were found in AZT-treated TG and WT. The pathological changes resembled findings with AZT treatment of other species (CocueraPindado et al, 1994; Lamperth et al, 1991; Lewis et al, 1991; McCurdy and Kennedy, 1998).

AZT damaged cardiac mitochondria in WT, with destruction, swelling, cristae dissolution, and fragmentation. Similarly, hearts from AZT-treated TG showed increased mitochondrial damage, but with greater intensity. Based on the ultrastructural findings, the HIV-1 transgene and AZT acted cooperatively to worsen mitochondrial damage.

On a clinical basis, the role of cardiac HIV-1 infection in AIDS CM remains controversial. HIV-1 was isolated and cultivated from an endomyocardial biopsy obtained from a patient with AIDS CM (Calabrese et al, 1987). Our group and others identified HIV-1 in human myocardial tissues by in situ hybridization with radiolabeled riboprobes (Grody et al, 1990; Lipshultz et al, 1990; Wu et al, 1990); but the overall pathogenic impact of HIV-1 in CM is not completely elucidated.

High-dose AZT caused mitochondrial CM, decreased cardiac mtDNA, and caused skeletal mitochondrial myopathy in rats (Cocuera-Pindado et al, 1994; Lamperth et al, 1991; Lewis et al, 1991; 1993; McCurdy and Kennedy, 1998, 1996). Those pathological observations correlated with inhibition of DNA polymerase- $\gamma$ in vitro by AZT triphosphate (Konig et al, 1989). Mixed inhibition kinetics were found with DNA polymerase- $\gamma$ extracted from the bovine heart (Lewis et al, 1994a) and DNA polymerase- $\gamma$ was among the most sensitive eukaryotic DNA polymerases to be inhibited by triphosphates of nucleoside analogs. Other thymidine analogs caused similar biochemical pathological changes (Lewis et al, 1994b, 1996). A proposed mechanism for mitochondrial toxicity from antiviral nucleoside analogs suggested altered mitochondrial biogenesis was crucial (Lewis and Dalakas, 1995).

Despite intriguing data in vivo and in vitro, the impact of antiretroviral therapeutics on the development of clinical AIDS CM remains unclear. In children, one group found progressive LV dilation in HIV-1infected pediatric patients irrespective of AZT therapy (Lipshultz et al, 1992). In contrast to the former findings, another report suggested AZT caused $\mathrm{CM}$ in HIV-1-infected children, whereas didanosine did not (Domanski et al, 1995). In primates, low-dose AZT treatment of the dam resulted in changes of mitochondrial structure and function in the heart and skeletal muscle of the fetus (Gerschenson et al, 1999). Previously, high-dose didanosine administration to Sprague-Dawley rats caused no mitochondrial lesions in the heart (Lewis et al, 1992). The relationship of AZT pharmacokinetic events in the cardiac myocyte (particularly nucleoside phosphorylation), tissue distribution and compartmentalization, and a "threshold effect" of AZT on mitochondrial dysfunction may all affect the development of CM in AIDS (Lewis and Dalakas, 1995; Wallace, 1999).

Recently, support emerged for the concept that altered mitochondrial DNA replication is linked to 

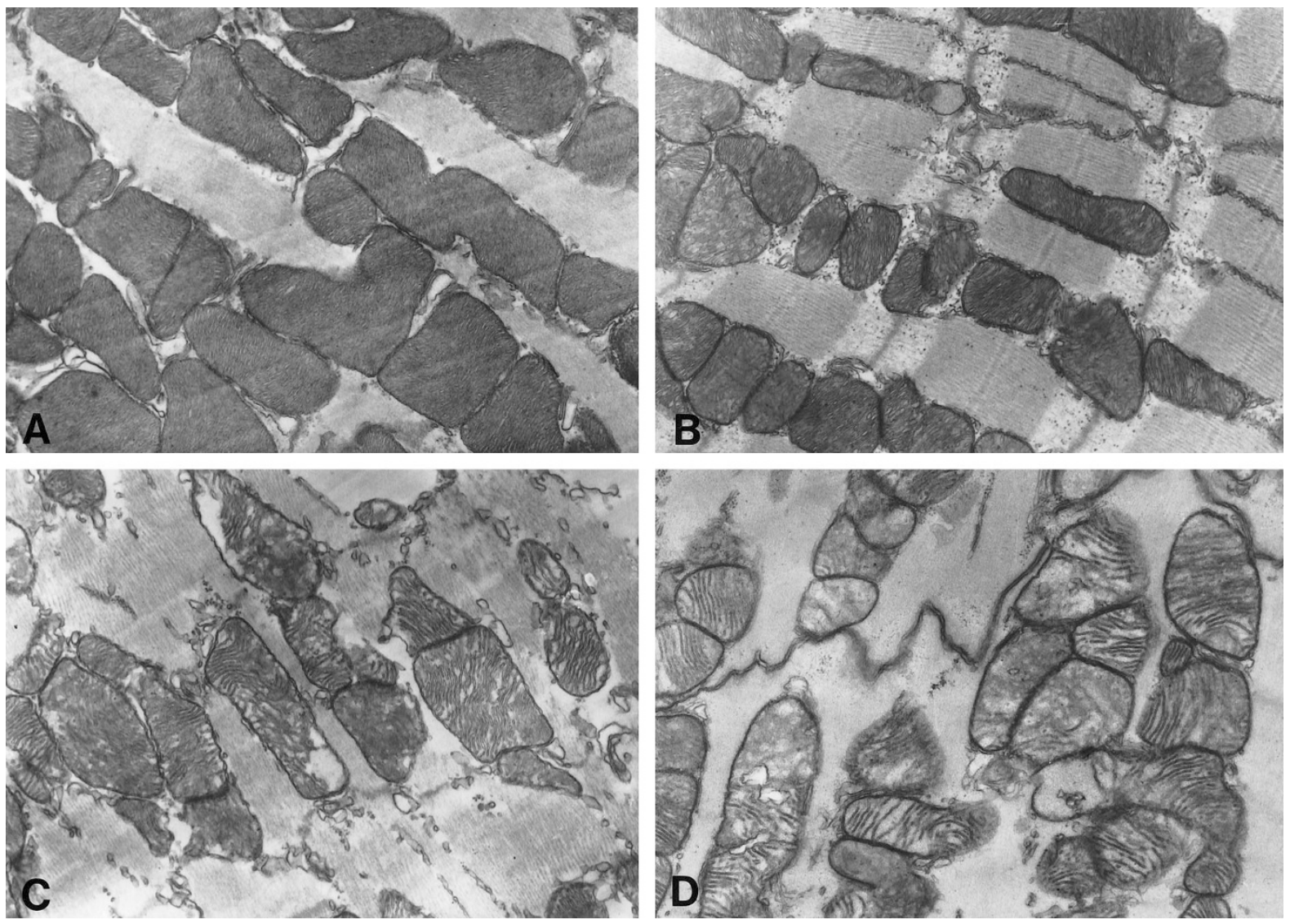

Figure 5 .

Ultrastructural changes in cardiac myocytes: With AZT treatment in both WT (C) and TG (D), mitochondrial changes of cristae dissolution and disruption were abundant compared with findings in hearts from WT (A). TG without AZT demonstrated minimal destruction of mitochondria (B). In AZT-treated WT (C) or AZT-treated TG (D), mitochondrial destructive change was increased compared with WT or TG. (Original magnification, $\times 14,000$ for each.)

Table 6. Fraction of Damaged Cardiac Mitochondria

\begin{tabular}{cccc}
\hline & $\begin{array}{c}\text { Mean \% } \\
\text { Mitochondrial } \\
\text { Damage }\end{array}$ & $\begin{array}{c}\text { Total Number of } \\
\text { Mitochondria } \\
\text { Viewed }\end{array}$ & $\begin{array}{c}\text { Total Number } \\
\text { of Damaged } \\
\text { Mitochondria }\end{array}$ \\
\hline WT $(n=7)$ & 2.3 & 925 & 21 \\
WT + AZT $(n=4)$ & 11.4 & 1538 & $175^{\star}$ \\
TG $(n=5)$ & 9.6 & 939 & 90 \\
TG + AZT $(n=5)$ & 42.4 & 1674 & $710 \dagger$ \\
\hline
\end{tabular}

${ }^{*} p<0.03$ compared with WT; $\uparrow p<0.00001$ compared with WT.

mitochondrial toxicity of nucleoside agents (Swartz, 1995; Wright and Brown, 1990). As a cautionary note, current doses of AZT in clinical use are not similar to those employed in experiments here on a $\mathrm{mg} / \mathrm{kg} / \mathrm{day}$ basis. Nonetheless, AZT doses used in the present study resemble those of other studies in different species (Lewis et al, 1991; 1992; McCurdy and Kennedy, 1996, 1998; Ruprecht et al, 1986) and similar findings occurred with low-dose AZT treatment of $E$. patas (Gerschenson, et al, 1999).

In summary, findings from this AIDS TG model implicate a transgenic HIV-1 construct in the mouse as a contributor to the development of $\mathrm{CM}$. The precise role of HIV-1 in cardiac dysfunction requires further exploration. AZT also contributes to structural and functional changes of mitochondrial CM in WT and TG mice. Pathophysiologic changes in WT resemble those found in other species. Contractility and relaxation were decreased significantly in TG. Mitochondrial damage observed in AZT-treated TG was greater than that found in untreated WT, untreated TG, or AZT-treated WT. Molecular correlates of CM were most striking in TG+AZT. They included increased steady-state abundance of mRNA encoding ANF and 
Table 7. Echocardiographic Data from TG and WT Treated with AZT (21 days)

\begin{tabular}{llclc}
\hline & WT $(n=3)$ & WT \pm AZT $(n=3)$ & TG $(n=3)$ & TG \pm AZT $(n=3)$ \\
\hline EDD & $3.21 \pm 0.18$ & $3.71 \pm 0.06$ & $3.09 \pm 0.19$ & $3.36 \pm 0.04$ \\
ESD & $1.98 \pm 0.11$ & $2.77 \pm 0.07^{\star}$ & $2.07 \pm 0.14$ & $2.42 \pm 0.24$ \\
FS & $38.2 \pm 0.4$ & $26.6 \pm 3.8^{\star}$ & $34.0 \pm 1.4$ & $28.1 \pm 6.4$ \\
PWT $_{\text {ed }}$ & $0.32 \pm 0.02$ & $0.36 \pm 0.01$ & $0.43 \pm 0.01$ & $0.37 \pm 0.05$ \\
SWT $_{\text {ed }}$ & $0.32 \pm 0.02$ & $0.35 \pm 0.01$ & $0.46 \pm 0.02$ & $0.38 \pm 0.02$ \\
h/r & $0.20 \pm 0.01$ & $0.19 \pm 0.01$ & $0.29 \pm 0.02$ & $0.22 \pm 0.23$ \\
LV mass & $20.7 \pm 2.3$ & $29.9 \pm 1.4^{\star}$ & $28.7 \pm 3.3$ & $26.4 \pm 2.2$ \\
\hline
\end{tabular}

Mean \pm SEM.

${ }^{*} \mathrm{p}<0.05$ vs WT.

EDD, end diastolic dimension; ESD, end systolic dimension; FS, fractional shortening; $\mathrm{PWT}_{\mathrm{ed}}$, posterior wall thickness; SWT $\mathrm{ed}_{\mathrm{e}}$, systolic wall thickness; h/r, wall thickness/cavity radium; LV mass, left ventricular mass.
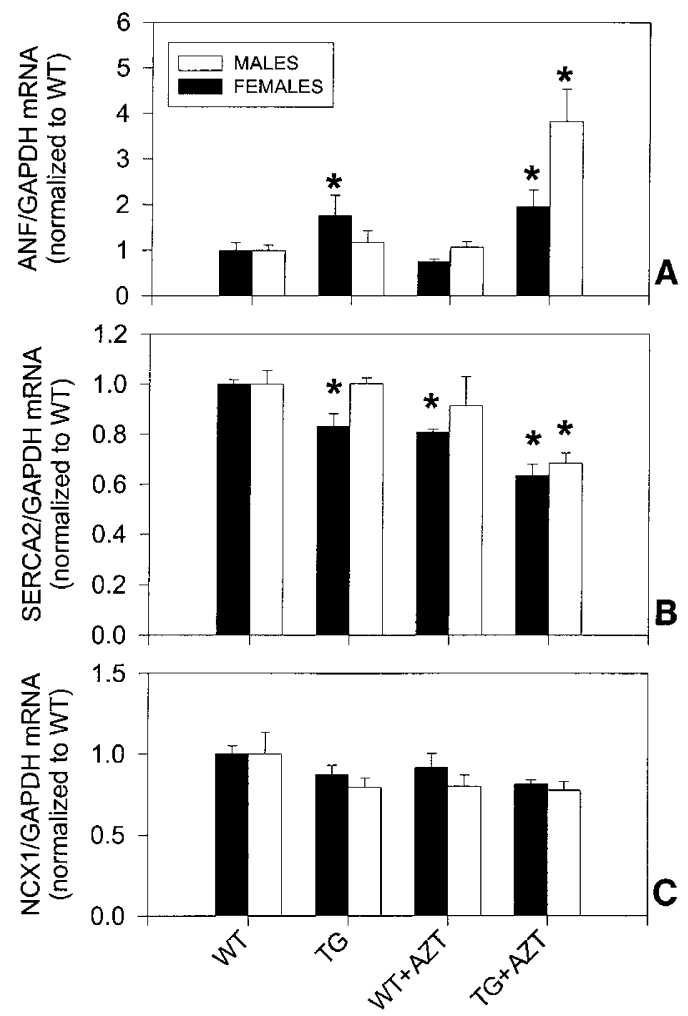

TREATMENT GROUPS

Figure 6 .

Alterations in atrial natriuretic factor and Ca transporter gene expression in transgenic and AZT-treated mice. Total RNA was isolated from the LV myocardium of male (open bars) and female (filled bars) WT and NL4-3A gag/pol TG mice. RNA was also isolated from male and female WT and TG animals that also received AZT. The RNA $(15 \mu \mathrm{g})$ was size-fractionated by denaturing agarose gel electrophoresis, transferred to nitrocellulose, and the resulting Northern blots were sequentially probed with ${ }^{32} \mathrm{P}$-labeled cDNA specific for atrial natriuretic factor (ANF), SR Ca ATPase (SERCA2), Na-Ca Exchanger (NCX1), and glyceraldehyde-3-phosphate dehydrogenase (GAPDH). The amounts of ANF and Ca transporter mRNA were quantified by scintillation spectroscopy, and are expressed relative to the amount of GAPDH mRNA. Data were further normalized to mRNA levels of the WT male or female animals. Data were compared by one-way ANOVA or Kruskal-Wallis one-way ANOVA by ranks, as appropriate. ${ }^{\star} p<0.05$ versus respective male or female WT animals; $n=4$ in each group.

decreased mRNA encoding SERCA2 in LV extracts. Echocardiographic correlates of $\mathrm{CM}$ were present after 21 days.
Together these data indicate that the TG and AZT treatment each contribute to cardiac dysfunction. The present studies indicate that transgenic mouse models of AIDS serve as useful tools to recapitulate and explore some features of human AIDS CM.

\section{Materials and Methods}

\section{Animals and Retrieval of Hearts}

Hemizygous TG employed for the study came from the colony established by Klotman and colleagues and were brought to the specific pathogen free barrier facility at our institution. Tg26 is a well-described murine line of NL4-3s gag/pol that develops nephropathy (Bruggeman et al, 1997; Kopp et al, 1992) skin lesions in hemizygotes and severe wasting in homozygotes (Kopp et al, 1993). For this study, a $2 \times 2$ protocol included both hemizygous TG and FVB/n (WT) treated with and without AZT for either 21 days (for echocardiographic and molecular studies) or 35 days (for isolated heart and pathological studies).

For both studies, each mouse received either water without drug or water containing AZT (courtesy of Glaxo Wellcome, Research Triangle, NC; $0.7 \mathrm{mg} / \mathrm{ml}$ ) ad libitum. Volume consumed was determined in individually housed mice, and amount of AZT (in $\mathrm{mg} / \mathrm{kg} /$ day) was derived. Fresh water was replenished on alternate days. Total AZT consumption and fractional consumption was determined for each mouse.

Preparation of the Heart for Physiological Measurements and Cardiac Performance Ex Vivo. The workperforming heart preparation was as described (Grupp et al, 1993; Jones et al, 1996). Mice were age-matched littermates (12 to 16 weeks after birth). For retrieval of the hearts, TG $(n=10)$ and WT $(n=11)$ were anesthetized with $30 \mathrm{mg} / \mathrm{kg}$ pentobarbital sodium injected ip with $500 \mathrm{U} / \mathrm{kg}$ of heparin sodium (ElkinsSinn, Cherry Hill, New Jersey) to prevent intracardiac blood coagulation. A 12-lead electrocardiogram was obtained and computation of heart rates was performed. For work-performing heart preparations, the hearts were removed through a midsternal incision, weighed, and immediately suspended on a 20-gauge stainless steel cannula and connected to the perfusion apparatus. Retrograde perfusion with heated $\left(37.4^{\circ} \mathrm{C}\right)$ and oxygenated Krebs-Henseleit buffer (KHS; con- 
taining, in $\mathrm{mm}$ : $118 \mathrm{NaCl}, 4.7 \mathrm{KCl}, 2.5 \mathrm{CaCl}_{2}, 1.2$ $\mathrm{MgSO}_{4}, 1.2 \mathrm{KH}_{2} \mathrm{PO}_{4}, 0.5 \mathrm{Na}-E D T A, 25 \mathrm{NaHCO}_{3}$, and 11 glucose) cleared the coronary vasculature of remaining blood and served to insert the left intraventricular catheter for pressure measurements. After a short stabilization period, the pulmonary vein was cannulated. Perfusion of the heart then was switched to anterograde. Venous return (preload) was adjusted and regulated with a micrometer and continuously measured using a dual channel Transonic flow meter (model T206; Transonic Systems, Ithaca, New York). Left ventricular pressure, aortic pressure, and left atrial pressure were measured with COBE pressure transducers.

Aortic flow was monitored on the second channel of the flow meter. Coronary flow was calculated. Aortic pressure (afterload) was adjusted with a second micrometer. Heart rate was computed with a Tachograph. The recording, amplification, and differentiation system was from Grass Instruments (models 7DA, 7PHA, 7P1, 720; Quincy, Massachusetts) and all parameters were analyzed and calculated with a custommade program. The fluid-filled catheter system responded well within experimental requirements, without distortion up to a frequency of $600 \mathrm{bpm}$. Heart rate was calculated from an ECG R-R interval. Values measured included: mean aortic pressure, IVP, peak systolic pressure, TPP/mmHg, $\mathrm{RT}_{1 / 2} / \mathrm{mmHg},+\mathrm{d} P / \mathrm{d} t$, aortic and coronary flow, venous return (cardiac output), left ventricular minute work (mean aortic pressure $\times$ cardiac output), stroke volume (cardiac output $\div$ heart rate), stroke work (stroke volume $\times$ mean aortic pressure), left atrial pressure, and perfusate temperature. The arterial $\mathrm{PO}_{2}$ was $650 \mathrm{mmHg}$, and the $\mathrm{PCO}_{2} \sim 30 \mathrm{mmHg}, \mathrm{pH}$ 7.4. The data from the working heart preparations were expressed as mean \pm SEM. Starling curves were generated by linear regression using Statview, version 4.01 (Abacus Concepts, Berkeley, California). Regression lines were compared using an $\mathrm{F}$ test.

Flow was adjusted to deliver an initial "venous return" of $\sim 5 \mathrm{ml} /$ minute and aortic pressure of 50 $\mathrm{mmHg}$. Cardiac function curves (Starling loading curves) were performed after stabilization of the heart in increasing and decreasing aortic pressure (pressure loading) followed by increasing and decreasing venous return (volume loading). Ventricular end-diastolic and left atrial pressures were monitored continuously.

Preparation for Histologic and Ultrastructural Examination. After physiological measurements were completed, each heart was placed on a Langendorff apparatus and fixed by perfusion at $50 \mathrm{mmHg}$ constant pressure (monitored) with 10\% neutral buffered formalin $(25 \mathrm{ml})$ for 5 minutes. The formalin-fixed heart was serially sectioned $(2 \mathrm{~mm})$ from apex to base. The second section (2 to $4 \mathrm{~mm}$ from apex) was further fixed in diluted Karnovsky's fixative and used for TEM (see below).

For histopathological evaluation, each heart slice was dehydrated through a graded series of alcohols, and paraffin embedded (uniformly oriented apex down). Serial sections from the paraffin-embedded tissue slice were stained with hematoxylin and eosin, and Masson's trichrome stain. Each tissue slice was examined microscopically. Photomicrography of the stained cross-section was performed with an Olympus photomicroscope (Olympus Optical, Tokyo, Japan).

Transmission Electron Microscopy. The LV free wall was identified in the perfusion-fixed 2-mm slices of heart. Slices of myocardium were sectioned longitudinally and transversely to generate $1-\mathrm{mm}$ cubes that were further fixed in $2 \%$ glutaraldehyde-cacodylate for 16 to 24 hours at $4^{\circ} \mathrm{C}$ for TEM. Each heart provided approximately 20 samples for embedding. Myocardium was rinsed in cold Ringer's solution and postfixed in $1 \% \mathrm{OsO}_{4}$ (Sigma, St. Louis, Missouri) in PBS, $\mathrm{pH} 7.4$, for 2 to 3 hours. After osmication and rinses, tissue was dehydrated with graded ethanols and embedded in Spurr (Spurr, 1969). Myocardial samples were sectioned $(100 \mathrm{~nm})$, stained with uranyl acetate, and examined on a JEOL-JEM-100CX electron microscope. (JEOL, Tokyo, Japan). For each embedded sample of myocardium, 10 random sections were selected and photographed at a uniform magnification $(14,000 x)$ by a single investigator.

Photomicrographs were enlarged to $8 \times 10$-inch prints and reviewed independently by two investigators for the presence of structurally abnormal mitochondria, for presence of intramitochondrial lamellar bodies, and for intramitochondrial paracrystals (Dalakas et al, 1990). Structurally abnormal mitochondria were operationally defined as mitochondria that had loss or dissolution of $\geq 25 \%$ of cristae by area. Damaged mitochondria were scored, and the fraction of damaged mitochondria was defined in the profiles. In each cohort, at least 60 myocyte profiles were examined.

Echocardiography of TG and WT with AZT Administration. Echocardiographic studies were performed in 10-week-old gender-matched (littermate) WT and TG that were treated with or without AZT for 3 weeks ( $n=3$ per cohort). Echocardiographic methods were described previously (Hoit et al, 1995, 1997 ; Kadambi et al, 1996). Briefly, mice were anesthetized with avertin $(0.25 \mathrm{mg} / \mathrm{g}$ of body weight) and twodimensionally targeted $\mathrm{M}$-mode studies were performed with a $9-\mathrm{MHz}$ imaging and a 5 to $7.75-\mathrm{MHz}$ Doppler transducer (Apogee X-200).

M-mode measurements of EDD, ESD, end-diastolic posterior wall thickness (EDPWTH), and end-diastolic septal wall thickness (EDSWTH) were made from original tracings. Calculated variables included: left ventricular fractional shortening (FS $=[E D D-E S D] /$ EDD), and LV mass (1.06 $\times[$ [EDD + EDPWTH + EDSWTH $\left.\left.]^{3}-(E D D)^{3}\right]\right)$, and the ratio of wall thickness to cavity dimension $(\mathrm{h} / \mathrm{r})$.

RNA Extraction from Hearts. For mRNA studies in the heart, treatment protocols were identical to those used above with AZT treatment of 21 days. Total RNA was isolated from LV tissue samples using the acid guanidinium thiocyanate-phenol-chloroform method (Chomczynski and Sacchi, 1987). RNA integrity was examined by electrophoresis and quantified as 260/ 
$280 \mathrm{~nm}$ absorbance ratio. Total RNA (10 to $20 \mu \mathrm{g}$ ) was size-fractionated by denaturing agarose gel electrophoresis and transferred by capillary action to nylon membranes for Northern blotting. Northern blots were sequentially probed with ${ }^{32} \mathrm{P}$-labeled cDNA probes specific for the SERCA2 (a 2.3-kb cDNA fragment of the rat cardiac SERCA2, provided by Dr. W. Dillmann, University of California, San Diego, California), NCX1 (a 1.5-kb cDNA fragment of guinea-pig cardiac sodium calcium exchanger from Dr. K. Philipson, University of California, Los Angeles, California), and ANF (a 0.8-kb cDNA fragment of rat ANF courtesy of $\mathrm{T}$. Inagama, Vanderbilt University, Nashville, Tennessee).

To ensure equal loading conditions and uniformity of transfer, hybridization signal intensity was normalized to the intensity of GAPDH mRNA. The cDNA probes were radiolabeled and hybridized as previously described (Eleftheriades et al, 1993). The amount of each respective mRNA relative to the amount of GAPDH mRNA was then quantified by autoradiography at $-80^{\circ} \mathrm{C}$ and laser densitometry of the signals and normalized to those from untreated controls.

Statistical Analysis. Steady-state abundance of mRNA, heart weights, and mitochondrial damage were compared by one-way ANOVA. Student $t$ tests were employed to compare the physiological data in isolated work-performing hearts. $p<0.05$ was used to establish significance.

\section{Acknowledgements}

Jay Card is acknowledged for excellent photography. We thank Georgianne Ciraolo, Heather McDermott, John Troutman, Traci Jackson, James Shmalo, Kevin Tankersley, Gilbert Newman, and Jennifer Matye for technical assistance and data processing.

\section{References}

Anderson D, Virmani R, Reilly JM, O'Leary T, Cunnion RE, Robinowitz M, Macher AM, Punja U, Villaflor ST, Parrillo JE, and Roberts WC (1988). Prevalent myocarditis at necropsy in the acquired immunodeficiency syndrome. J Am Coll Card 11:792-799.

Barbaro G, Barbarini G, and Di Lorenzo G (1996). Early impairment of systolic and diastolic function in asymptomatic HIV-positive patients: A multicenter echocardiographic and echo-Doppler study. AIDS Res Hum Retro 12:1559-1563.

Bruggeman LA, Dikman S, Meng C, Quaggin SE, Coffman TE, and Klotman PE (1997). Nephropathy in human immunodeficiency virus- 1 transgenic mice is due to renal transgenic expression. J Clin Invest 100:84-92.

Calabrese LH, Proffitt MR, Yen-Lieberman B, Hobbs RE, and Ratliff NB (1987). Congestive cardiomyopathy and illness related to the acquired immune deficiency syndrome (AIDS) associated with isolation of retrovirus from myocardium. Ann Int Med 107:691-692.

Cardoso JS, Moura B, Martins L, Mota-Miranda A, Gonçalves FR, and Lecour H (1998). Left ventricular dysfunction in human immunodeficiency virus (HIV)-infected patients. Int J Cardiol 63:37-45.
Chomczynski P and Sacchi N (1987). Single step method of RNA isolation by acid guanidinium thiocyanate phenol chloroform extraction. Analyt Biochem 162:156-159.

Cocuera Pindado MT, Lopez Bravo A, Martinez-Rodriguez R, Picazo Talavera A, Gomez A, Roldan Contreras M, Perez Alvarez MJ, Fernandez Garcia A, and Alonso Martin MJ (1994). Histochemical and ultrastructural changes induced by zidovudine in mitochondria of rat cardiac muscle. Eur $\mathrm{J}$ Histochem 38:311-318.

Cohen IS, Anderson DW, Virmani R, Reen BM, Macher AM, Sennesh J, DiLorenzo P, and Redfield RR (1986). Congestive cardiomyopathy in association with the acquired immune deficiency syndrome. N Engl J Med 315:628-630.

Coudray N, DeZuttere D, Force G, DeRibes C, Pourny J-C, Antony I, Lecarpentier Y, and Chemla D (1995). Left ventricular diastolic function in asymptomatic and symptomatic human immunodeficiency virus carriers: An echocardiographic study. Eur Heart J 16:61-67.

Currie PF and Boon NA (1983). Cardiac involvement in human immunodeficiency virus infection. Q J Med 86:751753.

Dalakas MC, Illa I, Pezeshkpour G, Laukaitis J, Cohen B, and Griffin J (1990). Mitochondrial myopathy caused by long term zidovudine therapy. N Eng J Med 322:1098-1105.

De Palo VA, Millstein BH, Mayo PH, Salzman SH, and Rosen MJ (1995). Outcome of intensive care in patients with HIV infection. Chest 107:506-510.

Domanski MJ, Sloas MM, Follmann DA, Scalise PP, Tucker EE, Egan D, and Pizzo PA (1995). Effect of zidovudine and didanosine treatment on heart function in children infected human immunodeficiency virus. J Pediat 127:137-146.

Eleftheriades EG, Durand J-B, Ferguson AG, Engelmann GL, Jones SB, and Samarel AM (1993). Regulation of procollagen metabolism in the pressure-overloaded rat heart. J Clin Invest 91:1113-1122.

Gerschenson M, Paik CY, Erhart SW, and Poirier MC (1999). Exposure of pregnant patas monkeys to $3^{\prime}$-azido-2', $3^{\prime}$ dideoxythymidine (AZT) produces damaged mitochondria and abnormal energy metabolism in the fetal cardiac and skeletal muscle tissues (Abstract). FASEB J A488.

Grody WW, Cheng L, and Lewis W (1990). Infection of the heart by the human immunodeficiency virus. Am J Cardiol 66:203-206.

Grupp IL, Subramaniam B, Hewett TE, Robbins J, and Grupp G (1993). Comparison of normal, hypodynamic and hyperdynamic mouse hearts using isolated work-performing heart preparations. Am J Physiol 265:H1401-1410.

Herskowitz, A, Willoughby SB, Baughman KL, Schulman SP, and Bartlett JD (1992). Cardiomyopathy associated with antiretroviral therapy in patients with HIV infection: A report of 6 cases. Annals Int Med 116:311-313.

Hoit BD, Khan ZU, Pawloski-Dahn C, and Walsh RA (1997). In vivo determination of left ventricular shortening and wall stress relationship in normal mice. Am J Physiol 272:H1047H1052.

Hoit BD, Khoury SF, Kranias EG, Ball N, and Walsh RA (1995). In vivo echocardiographic detections of enhanced left ventricular function in gene targeted mice with phospholamban deficiency. Circ Res. 77:632-637. 
Hsia JA and McQuinn LB (1993). AIDS cardiomyopathy. Res Staff Physician 39:21-24.

Jacob AJ, Sutherland GR, Boon NA, and Ludlam CA (1993). Dilated cardiomyopathy in haemophiliacs infected with the human immunodeficiency virus. Scottish Med J 38:112-113.

Jones WK, Grupp IL, Doetschman T, Grupp G, Osinska H, Hewett TE, Boivin G, Gulick J, Ng WA, and Robbins J (1996). Ablation of the murine (myosin heavy chain gene leads to dosage effects and functional deficits in the heart. $\mathrm{J}$ Clin Invest 98:1906-1917.

Kadambi VJ, Ponniah S, Harrer JM, Hoit BD, Dorn GW II, Walsh RA, and Kranias EG (1996). Cardiac specific overexpression of phospholamban alters calcium kinetics and resultant cardiomyocyte mechanics in transgenic mice. J Clin Invest 97:533-539.

Klotman PE and Notkins AL (1996). Transgenic models of human immunodeficiency virus type-1. Curr Top Micro Immun 206:197-222.

König H, Behr E, Lower J, and Kurth R (1989). Azidothymidine triphosphate is an inhibitor of both human immunodeficiency virus type 1 reverse transcriptase and DNA polymerase- $\gamma$. Antimicrob Agents Chemo 33:2109-2114.

Kopp JB, Klotman ME, Adler SH, Bruggeman LA, Dickie P, Marinos NJ, Eckhaus M, Bryant JL, Notkins AL, and Klotman PE (1992). Progressive glomerulosclerosis and enhanced renal accumulation of basement membrane components in mice transgenic for human immunodeficiency virus type 1 genes. PNAS (USA) 89:1577-1581.

Kopp JB, Rooney JF, Wohlenberg C, Dorfman N, Marinos NJ, Bryant JL, Katz SI, Notkins AL, and Klotman PE (1993). Cutaneous disorders and viral gene expression in HIV-1 transgenic mice. AIDS Res Hum Retrovir 9:267-275.

Lamperth L, Dalakas MC, Dagani F, Anderson J, and Ferrari $R$ (1991). Abnormal skeletal and cardiac mitochondria induced by zidovudine (AZT) in human muscle in vitro and in an animal model. Lab Invest 65:742-751.

Lewis W (1998). Mitochondrial toxicity of antiviral nucleosides used in AIDS: Insights derived from toxic changes observed in tissues rich in mitochondria. In: Lipshultz SE, editor. Cardiology in AIDS. New York: Chapman \& Hall, 307-316.

Lewis W, Chomyn A, Gonzalez B, and Papoian T (1992). Zidovudine induces molecular, biochemical and ultrastructural changes in rat skeletal muscle mitochondria. J Clin Invest 89:1354-1360.

Lewis W and Dalakas MC (1995). Mitochondrial toxicity of antiviral drugs. Nature Med 1:417-422.

Lewis W, Levine ES, Griniuviene B, Tankersley KO, Colacino JM, Sommadossi, J-P, Watanabe K, and Perrino FW (1996). Fialuridine and its metabolites inhibit DNA polymerase- $\gamma$, substitute for thymidine DNA, decrease mtDNA abundance, and cause mitochondrial structural defects in cultured hepatoblasts. PNAS (USA) 93:3592-3597.

Lewis W, Papoian T, Gonzalez B, Louie H, Kelly DP, Payne RM, and Grody WW (1991). Mitochondrial ultrastructural and molecular changes induced by zidovudine in rat hearts. Lab Invest 65:228-236.
Lewis W, Papoian T, and Kennedy P (1992). Cardiotoxicity of dideoxynucleosides in rats includes morphologically distinct and selective myocardial lesions (Abstract). J Cell Biochem 16E:83.

Lewis W, Simpson JF, Colacino JM, Perrino FW, and Meyer RR (1994a). Fialuridine (FIAU) Triphosphate competitively inhibits mitochondrial DNA polymerase- $\gamma$. Biochemistry 33: 14620-14624.

Lewis W, Simpson JF, and Meyer RR (1994b). Cardiac mitochondrial DNA polymerase- $\gamma$ is inhibited competitively and non-competitively by phosphorylated zidovudine. Circ Res 74:344-348.

Lipshultz SE, Fox CH, Perez-Atayde AR, Sanders SP, Colan SD, McIntosh K, and Winters HS (1990). Identification of human immunodeficiency virus-1 RNA and DNA in the heart of a child with cardiovascular abnormalities and congenital acquired immune deficiency syndrome. Am J Cardiol 66: $246-250$.

Lipshultz SE, Oray J, Sanders SP, Hale AR, Mclntosh K, and Colan SD (1992). Cardiac structure and function in children with human immunodeficiency virus infection treated with zidovudine. N Engl J Med 327:1260-1265.

McCurdy DT III and Kennedy JM (1996). Skeletal muscle mitochondria from AZT-treated rats have a diminished response to chronic electrical stimulation. J Appl Physiol 81:326-334.

McCurdy DT III and Kennedy JM (1998). AZT decreases rat myocardial cytochrome oxidase activity and increases $\beta$-myosin heavy chain content. J Mol Cell Cardiol 30:19791989.

Michael A, Lederman RJ, MacGregor JS, and Cheitlin MD (1997). Cardiovascular involvement in AIDS. Current Prob Cardiol 23:112-148.

Reilly JM, Cunnion RE, Anderson, DW, O'Leary TJ, Simmons JT, Lane HC, Fauci, AS, Roberts WC, Virmani R, and Parrillo JE (1988). Frequency of myocarditis, left ventricular dysfunction and ventricular tachycardia in the acquired immune deficiency syndrome. Am J Cardiol 62:789-793.

Ruprecht RM, O'Brien LG, Rosson LD, and NusinoffLehrman S (1986). Suppression of mouse viraemia and retroviral disease by $3^{\prime}$-deoxythymidine. Nature 323:467469.

Spurr AA (1969). A low viscosity epoxy resin embedding medium for electron microscopy. J Ultrastruct Res 26:31-43.

Swartz MN (1995). Mitochondrial toxicity: New adverse drug effects. N Engl J Med 333:1146-1148.

Wallace DC (1999). Mitochondrial disease in man and mouse. Science 283:1482-1488.

Wright GE and Brown NC (1990). Deoxyribonucleotide analogs as inhibitors and substrates of DNA polymerases. Pharmac and Ther 47:447-497.

Wu AY, Forouhar, F, Cartan RW, Betrman MM, Shiue ST, Louie AT, and Grunnet M (1990). Identification of human immunodeficiency virus in the heart of a patient with acquired immunodeficiency syndrome. Mod Pathol 3:625-630. 